\title{
MISCELLANEA
}

\section{MALÝ NÁHLED DO SVĚTA SBĚRATELŮ KURIOZIT V 16.-18. STOLETÍ}

\author{
Alena Císařová Smítková (Praha)
}

\begin{abstract}
A Little Insight into the World of Curiosity Collectors in the 16th-18th Centuries
Abstract: The origins of collecting are as old as humanity itself, and practically anything can be collected. In the 16th century, it became fashionable to collect natural peculiarities with the aim to create so-called cabinets of curiosities. The owners were distinguished and wealthy people with high social status and scholars. The most important and largest collections were owned by Archduke Ferdinand II of Austria at Ambras Castle and Emperor Rudolf II in Prague. The cabinets of the Danish physician Ole Worm and the German Jesuit Athanasius Kircher were also prominent. The first comprehensive study of natural history collections in Europe is the richly illustrated work Museum Museorum by Michael Bernhard Valentini from the early 18 th century.
\end{abstract}

Keywords: collecting - cabinets of curiosities - 16th-18th centuries - Ferdinand II, Archduke of Austria (1529-1595) - Rudolf II, Holy Roman Emperor (1552-1612) - Michael Bernhard Valentini (1657-1729)

Když se řekne slovo sbírka nebo sběratelství, možná se mnohým z nás $\mathrm{v}$ duchu vybaví dětská léta a s nimi i vzpomínka na první alba známek, etiket, lístků či obrázků, desky plné odznaků, nebo třeba první herbáře. Ano, je možné sbírat prakticky cokoliv, na co si člověk vzpomene. Vždyt' existuje také nepřeberné množství sběratelských oborů. ${ }^{1}$ Ale abychom pochopili samotný fenomén sběratelství, museli bychom zabrousit spíše do psychologie, ${ }^{2}$ protože ač je to záliba bohulibá a relaxační, tak každý sběratel prožívá vlastně stále dokola několik různých stavů.

Sbírání či shromažd'ování různých věcí je staré jako lidstvo samo. Vždyt' první lidé byli přece lovci a sběrači. Tento ušlechtilý koníček najdeme naprríč celým světem a není nijak omezen, věnují se mu muži i ženy všech věkových kategorií. Lze jej vystopovat od antických soch přes středověké relikvie až po současná moderní, oborově zaměřená muzea a galerie. Významný rozmach zaznamenalo sběratelství v 15. století, když se ve společnosti prosadilo znovuzrození, neboli renesance - umělecký i životní styl pomyslně završující epochu středověku, původem z Itálie. Období s nebývale prríznivými podmínkami pro rozvoj umění a prrírodních i humanitních věd ovlivňovalo lidstvo od 14. do 16. století. Během 16.-17. století byl renesanční návrat $\mathrm{k}$ antice postupně nahrazen barokní zbožností a velkolepostí. Obroda křest'anství díky vítězství protireformace a následné upevnění moci církve i panovníků se projevily ve všech druzích umění, jehož cílem bylo jediné: všemi prostředky připomenout člověku pokoru a oddanost Bohu. ${ }^{3}$ Ale jako dosud každý směr v dějinách lidstva, byl i tento záhy překonán. Z odmítání přehnaného barokního uctívání vzešlo osvícenství, životní postoj a filozofie 17.-18. století. ${ }^{4}$ Do popředí se dostal racionalismus a logika, nastala krize vědeckých disciplín, hroutily se dosud uznávané středověké teorie a zájem se začínal opět obracet k př́rodě.

Šestnácté století lze chápat jako milník, kdy byly položeny základy většiny dnes proslulých sbírek a u zrodu mnoha z nich stály původně středověké poklady. Sbíraly se nejen drahé kameny, šperky a umělecká díla, ale do popředí zájmu se dostávaly i různé přírodní anomálie či naopak ryze praktické věci jako nářadí a nástroje. Znalec umění, rakouský malír̆ a grafik Gabriel Kaltemarckt († asi 1611) sepsal pro saského kurfiřta Kristiána I. (1560-1591) rady a doporučení ohledně

\footnotetext{
Ke sběratelství obecně např. BLOM 2003; BROŽKOVÁ - CIRKL - DRAHOTOVÁ - ROUS - SLAVÍČEK 1983; MacGREGOR 2007; PICKA 2008; RAVIK 1994; RAVIK 2010 nebo vysokoškolská skripta DOLÁK 2018. Specializované publikace dle oborů např. AUGUSTA 1927; KNÁPEK 1998-2002; KUDWEIS 2017 a další oborové, převážně periodické publikace např. Antique, Filumenie, Filatelie, Postilión, Sběratel, Sběratelské noviny atd.

2 Psychologické stránce se věnují např. Carl Gustav Jung, Sigmund Freud, Werner Muensterburger nebo Donald Winnicott.

3 Z bohaté literatury k baroku např́iklad KALISTA 2014; NEUMANN 1969; TOMAN 2013; VILLARI 2004.

${ }^{4}$ K osvícenství například BIET et al. 1995; BLACK 2003; HALADA 1984; STARK 2008.
} 


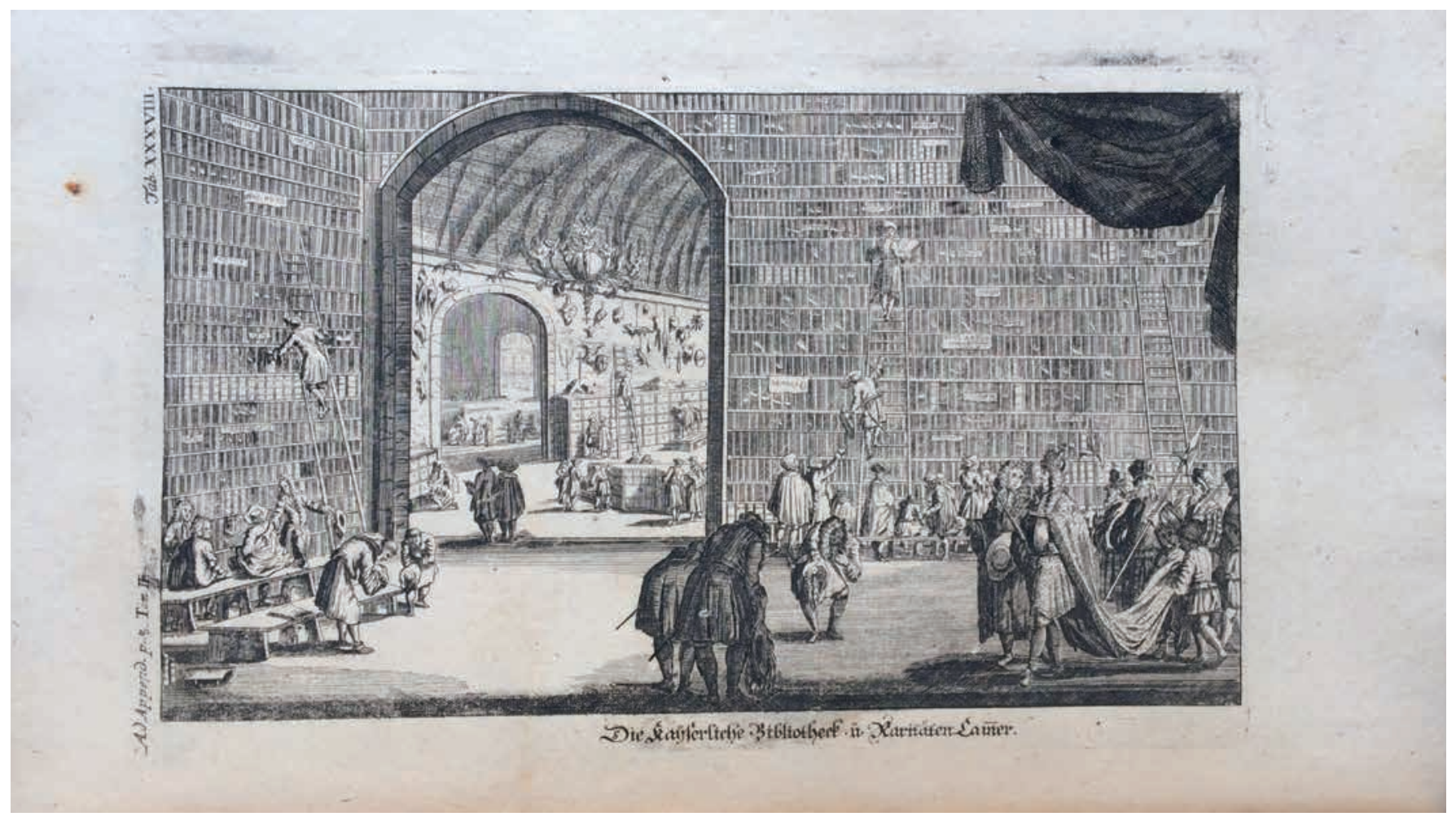

Obr. 1. Císařská knihovna a za ní kunstkomora ve Vídni. NK ČR, sign. 65 B 216/adl.1.

sbírek a jejich uspořádání. Dokument o 50 stranách datoval 2. června $1587,{ }^{5}$ po svém návratu z Itálie, kde měl možnost studovat medicejské sbírky a navázal kontakty s obchodníky uměním. Snažil se přesvědčit Kristiána I. o změnách, které by drážd’anské sbírce, založené již roku 1560 jeho otcem Augustem I. (1526-1586), jedině prospěly. Sbírka byla dosud prezentována hlavně s důrazem na vědecký a technický prínos, ale Kaltemarckt chtěl naopak vyzdvihnout hledisko estetické a dát větši prostor sochám a výtvarnému umění. Tvrdil, že ve správném kabinetu kuriozit by neměly chybět rozhodně sochy a obrazy, kuriozity a zvláštnosti z domova i ciziny a různé trofeje podivných a exotických zviŕat. Tyto tři skupiny, považované za základní kameny sbírek, skutečně také v téměř žádné významné sbírce nechyběly.

Patřičné předměty byly postupně shromažd'ovány a kupovány, sbírky se stávaly fenoménem mezi bohatými a významnými osobnostmi. Téměř každý panovník, velvyslanec nebo učenec měl svůj kabinet kuriozit (čili kunstkomoru, ${ }^{6}$ jak se také sbírkám ŕíkalo), kterým se rád pochlubil. Jejich účelem bylo $\mathrm{v}$ mnoha prípadech hlavně ohromit, at' už samotnými exponáty, nebo vědomím, jaké na to dotyčný vynaložil finanční prostředky. Kromě pouhého shromažd’ování, jak by se mohlo na první pohled snad zdát, byla posláním sbírek snaha proniknout do tajemství života a prírody, ale zároveň měly sloužit i jako zdroj informací pro učence, vědce nebo řemeslníky.
Kabinety kuriozit měly také své katalogy, z nichž některé byly vydány tiskem. Za první vyobrazení prírodovědného kabinetu je pokládána rytina neapolského lékárníka Ferranta Imperata (asi 1525-1615) v jeho díle Dell'Historia Natvrale di Ferrante Imperato Napolitano Libri XXVIII., vydaném v Neapoli roku 1599.7 Imperato byl typickým renesančním vědcem a humanistou a svůj vlastní kabinet zde zobrazil na dvoustraně za titulním listem. Jedná se o jedinou místnost s oknem, při jedné stěně stojí knihovny plné knih a na nich jsou umístěny mořské korály. Můžeme se jenom domýšlet, že některé z knih představují Imperatův herbár. Uprostřed klenutého stropu je zavěšen vycpaný krokodýl a okolo něj jsou soustředěni drobnější savci, preparované ryby a množství různých lastur a mořských hvězdic. Naproti knihovně se nalézají vestavěné skř́ně, vyobrazené $\mathrm{s}$ otevřenými dviŕky, $\mathrm{v}$ nichž jsou zobrazeny rozličné nádoby, krabice a krabičky, nepochybně skrývající další exponáty, pravděpodobně charakteru mineralogického. Na otevřených policích stojí vycpaní ptáci. Dalo by se říci, že zde vyobrazený kabinet kuriozit může sloužit jako modelový př́klad pro popis dalších. Vystavené exponáty byly sice odlišné, ale uspořádání vesměs podobné.

\section{Sbírka Ferdinanda II. Tyrolského}

Nejproslulejší sbírku vlastnil v 16. století rakouský arcivévoda Ferdinand II. Tyrolský (1529-1595), strýc

\footnotetext{
${ }^{5}$ Dokument má název Bedencken, wie eine kunst-cammer aufzu richten seyn mochte a měl by být dnes uložen v saském archivu v Drážd’anech. Edice dokumentu DÄMMIG 2012. Dále k témuž např. GALLIAN 2020 a GUTFLEISCH-ZICHE - MENZHAUSEN 1989.

${ }^{6}$ Ke kunstkomorám obecně např. DAVENNE 2012; DEMEULEMEESTER 2017; MAURIES 2011.

${ }^{7}$ DigitálníkopienaK10plus.Dostupnéz:https://gdz.sub.unigoettingen.de/id/PPN487769457?tify=\{\%22pages\%22:[10],\%22view\%22:\%22info\%22\} [cit. 31. 8. 2021].
} 
budoucího císaře Rudolfa II. Habsburského (1552-1612). Druhý syn ř́mského císaře Ferdinanda I. (1503-1564) a Anny Jagellonské (1503-1547) zastával v letech 15471567 úřad královského místodržícího v Čechách. V době vrcholící éry renesance a humanismu zřídil v Praze svou rezidenci a zasloužil se o kulturní i vědecký rozkvět našich zemí. Zakládal zahrady a obory, jelikož součástí renesančního pojetí života bylo i sepětí s př́rodou, projektoval vlastní stavby a všestranně podporoval umění. Podle jeho návrhu byl postaven i letohrádek Hvězda, ${ }^{8} \mathrm{kde}$ byly původně umístěny jeho umělecké sbírky.

Určitě největším arcivévodovým koníčkem byly zbraně a zbroj, jeho sbírka je dnes považována ve světě za jednu z nejvýznamnějších. Věnoval se ale $\mathrm{i}$ dalším sběratelským oblastem, měl početnou sbírku portrétů, mincí, prrírodních kuriozit, vědeckých přístrojů, hodin, hudebních nástrojů a uměleckých předmětů. Jako první koncipoval svou sbírku podle systematického hlediska. Shromáždit a uspořádat takové množství bylo jistě časově i finančně velmi náročné. Část exemplářu zdědil po svém otci, jak dokazuje dochovaný inventár numismatické sbírky z rozmezí let 1547-1550, ${ }^{9}$ sestavený císařským pokladníkem Leopoldem Heypergerem (1504-1564) právě pro císaře Ferdinanda I. Ten jmenoval roku 1547 Heypergera purkrabím paláce Hofburg a zároveň i správcem císařské kunstkomory, v kteréžto funkci setrval do roku $1560 .{ }^{10} \mathrm{Když} \mathrm{po} \mathrm{smrti} \mathrm{otce} \mathrm{roku} 1564$ převzal vládu v Tyrolsku Ferdinand II., nechal své sbírky převézt na zámek Ambras v Innsbrucku, kde se dochovaly dodnes jako jediná renesanční kunstkomora na původním místě. ${ }^{11}$ Tato kulturní památka bývá někdy označována za nejstarší muzeum na světě a její zakladatel Ferdinand II. po právu za jednoho z nejvýznamnějších sběratelů historie.

\section{Rudolfinské sbírky}

Největší a nejvýznamnější kunstkomoru na sever od Alp však vlastnil na počátku 17. století císař Rudolf II. v Praze na Hradčanech. Nechal pro své sbírky postavit kolem roku 1600 zvláštní budovu, tzv. Střední trakt. Rozsah jeho zájmů byl fenomenální a vynakládané finance téměř neomezené, což také přispělo k velkému zadlužení. Sbíral a shromažd'oval předměty ze všech oblastí, at' již vzniklé lidskou činností, či zásluhou matky prírody. Zřejmě rozhodujícím faktorem bylo pro císaře hledisko estetické. Početné sbírky výtvarného umění byly vyděleny zvlášt' a samotná hlavní kunstkomora - vybavená 20 skř́iněmi, jejichž obsah známe pouze částečně, a několika truhlami a šperkovnicemi - měla ještě tři předcházející vedlejší místnosti s dalšími 17 skříněmi, stoly a truhlami. ${ }^{12}$

Složení císařských sbírek bylo v mnoha ohledech jedinečné, představovalo ve své podstatě malou encyklopedii

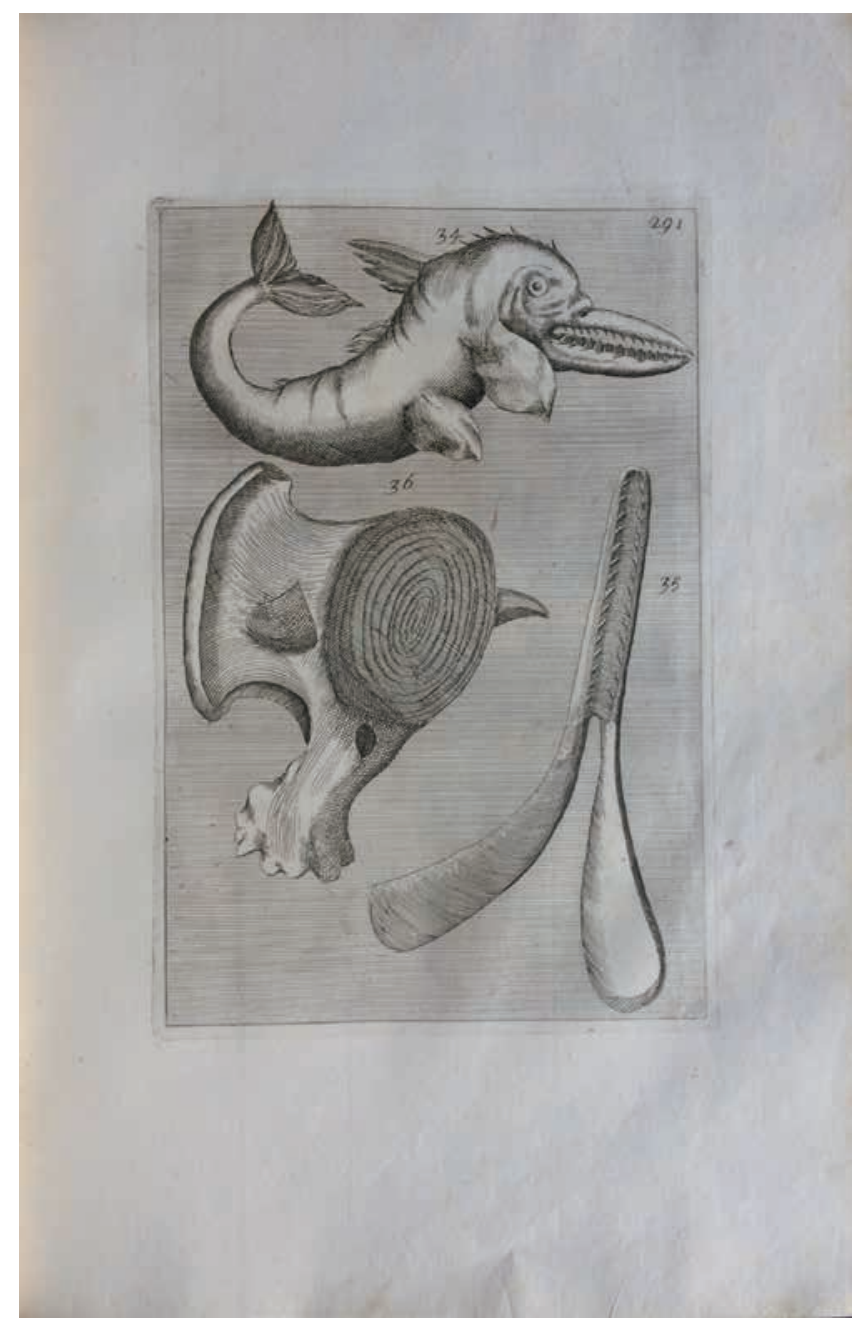

Obr. 2. Vorvaň obrovský (Physeter macrocephalus). Části velrybích koster byly mezi sběrateli oblíbeným artiklem. NK ČR, sign. 23 A 11 .

lidského vědění a umění. Nalezli bychom zde předměty od krásného umění až po válečné, například sochy a obrazy, šperky, sklo a porcelán, př́rodovědné exponáty z oblasti fauny, flóry i geologie, starožitnosti, mince a medaile, hodiny, glóby, vědecké př́stroje, nástroje řemeslné i hudební, knihy, rukopisy a grafické listy, nebo zbraně či zbroj.

Základ rozsáhlým pražským sbírkám položil odborník na slovo vzatý, italský učenec, historik a antikvář Jacopo de Strada (1507-1588). Známého sběratele starožitností, který v Norimberku pracoval pro rodinu Fuggerů a je dnes považován za zakladatele vědecké numismatiky, ${ }^{13}$ pověřil pořádáním a rozšiřováním svých vídeňských sbírek již Ferdinand I. Habsburský a po něm Maxmilián II. (15271576). Po jeho smrti přešel do služeb dalšího císaře, Rudolfa II. Možná si někdo vybaví známou scénu s obrazem Mony Lisy z neméně známé komedie Císařùv pekař - Pekařùv

\footnotetext{
${ }^{8}$ DOBALOVÁ - HAUSENBLASOVÁ - MUCHKA - PURŠ 2014.

${ }^{9} \mathrm{O}$ historii sbírek viz stránky Kunsthistorisches Museum Wien. Dostupné z: www.khm.at [cit. 7. 9. 2021].

${ }^{10}$ BERGMANN 1844-1857.

${ }^{11}$ Více na oficiálních webových stránkách zámku: Schloss Ambras. Dostupné z: www.schlossambras-innsbruck.at [cit. 7. 9. 2021].

${ }^{12}$ BUKOVINSKÁ 1997. Dále např. GRANBERG 1902; DACOSTA KAUFMANN 1978; FUČÍKOVÁ - BUKOVINSKÁ - MUCHKA 1991; JANÁČEK 2014.

${ }^{13}$ STRADA 1553. Strada je autorem odborného spisu Epithome thesavri antiqvitatvm, obsahujícího životopisy římských císařů od Julia Caesara po Maxmiliána II. včetně jejich podobizen zhotovených právě podle zobrazení na dobových mincích. NK ČR, sign. 23 H 42.
} 


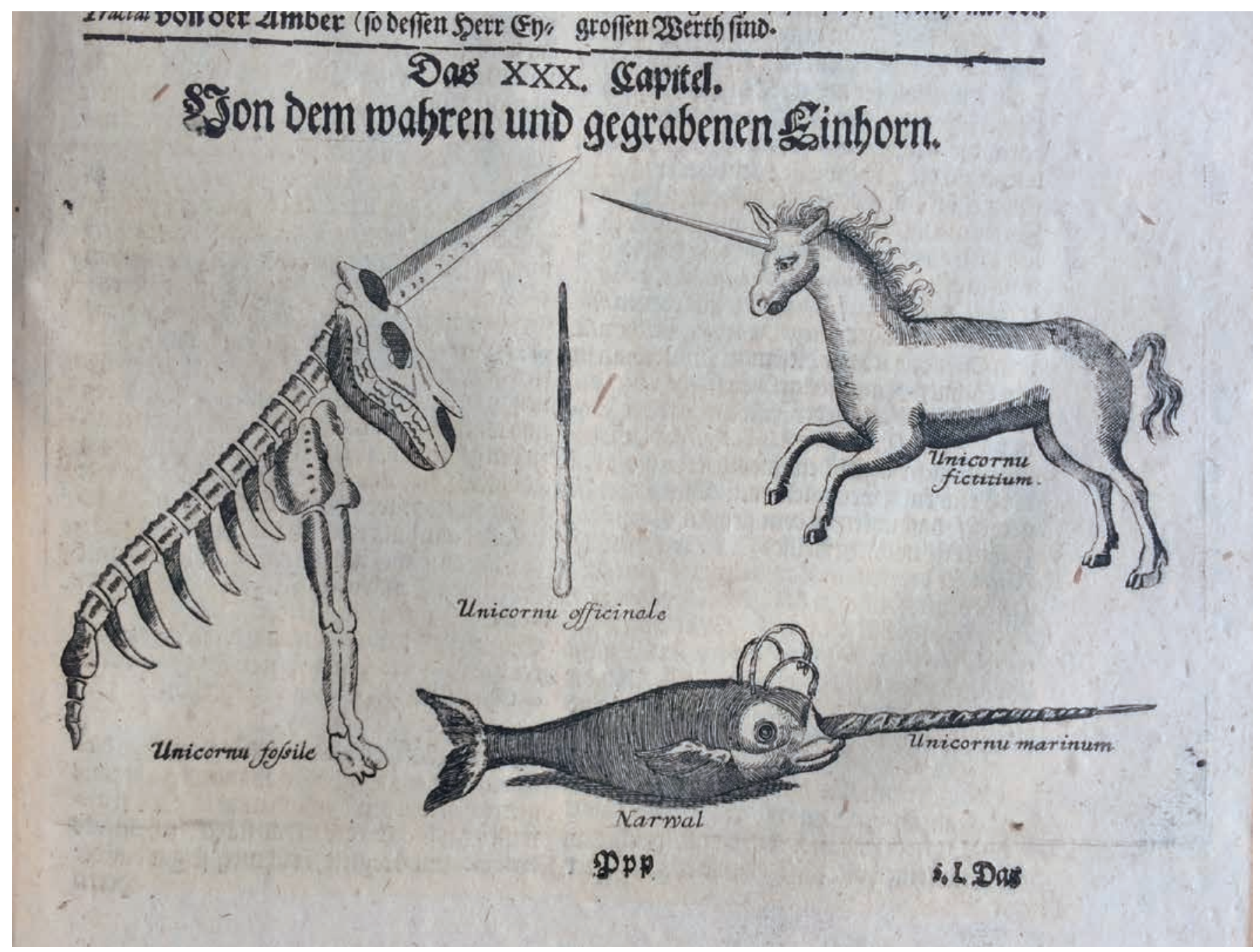

Obr. 3. Bájný jednorožec a pravý nositel „rohu“ narval jednorohý (Monodon monoceros). NK ČR, sign. 65 B 216.

císař. Strada nakupoval umělecké předměty po celém světě a pilně rozšiřroval císařské i svoje sbírky. Roku 1577 zakoupil dům na Starém Městě pražském a v Praze byl také roku 1588 pochován. V rodinné tradici úspěšně pokračoval jeho syn Ottavio Strada z Rossbergu (1550-1606), který převzal úruad dvorního antikváře císaře Rudolfa II. a po otcově smrti zdědil i rodinné sbírky. U svého otce Jacopa vyučený kreslír a antikvář si brzy získal císařovu přízeň a kromě péče o sbírky byl jmenován také jeho dvorním malírem. ${ }^{14}$

Po Stradových se stal správcem císařských sbírek roku 1607 německý malíŕ Daniel Fröschl (1572/73-1613), jehož specializací byla malba miniatur. Dostal za úkol kromě správy rozsáhlých sbírek hlavně jejich inventarizaci. Předměty z různých oblastí lidské činnosti byly zpočátku ve sbírkách pouze soustředěny na jednom místě, často uložené nepřehledně ve velkém množství na policích ve skříních a vitrínách. Zhruba od 17. století začaly být $\mathrm{v}$ kabinetech vydělovány sekce prrírodovědné. Jak se prostory pro ukládání sbírek zvětšovaly, byly exponáty postupně řazeny tematicky a s větším důrazem na jejich viditelnost, $v$ čemž můžeme vypozorovat první základy budoucích muzeí. ${ }^{15}$ Fröschl při práci na inventáři využil svého umění a některé exponáty kromě pečlivého popisu také nakreslil. O čtyřri roky později, v roce 1611 , byl rukopis o 415 stranách dohotoven. Dělil předměty na tři hlavní skupiny: naturalia (prírodniny), artificialia (umělecké výtvory) a scientifica (vědecké př́stroje a nástroje). Kategorie přírodnin naprríklad obsahuje necelé trri tisíce položek od minerálů přes fosilie, herbáře, exotické plody, korály, mušle, vycpaná zvířata či jejich artefakty až po nezbytný roh jednorožce čili narvalí kel. Druhý inventáŕ vznikl o osm let později z popudu českých stavů a třetí, nejúplnější, zahrnující i tři místnosti ,předkomory“, roku 1621 z př́kazu královského místodržícího knížete Karla I. z Lichtenštejna (1569-1627). ${ }^{16}$

S Rudolfovou smrtí ale pomalu zaniklo i jeho velké dílo, označované za největší muzeum jediného majitele a oceněné speciální komisí na neuvěřitelných 17 milionů guldenů. Rozsáhlé sbírky přešly postupně do rukou mladšího bratra, císaře Matyáše (1557-1619), a dalších členů habsburského rodu jako součást dědictví. Nový císař si mnoho cenných předmětů odvezl hned roku 1612 do Vídně, ostatní členové

\footnotetext{
${ }^{14}$ Ottưv slovník naučný, díl 24, s. 180-181.

${ }^{15}$ IMPEY - MACGREGOR $2018^{2}$

16 Jediný exemplár se nachází v Zemské knihovně ve Vaduzu - viz FINDLEN 1997, s. 209-219.
} 
pak své podíly na rodová sídla. Druhý větší celek byl převezen do Vídně roku 1631, když saská vojska obléhala Prahu. Ale největší část sbírek padla roku 1648 do chřtánu švédských rabujících vojsk. Ani „loupež století'“ nebyla ještě konečná a rozprodej rudolfinských sbírek pokračoval až do poslední dražby roku $1783 .{ }^{17}$

\section{Sbírky Olava Worma}

Následující dvě v tehdejším sběratelském prostředí velmi ceněné sbírky, i když zdaleka ne tak excelentní, jako byla ta Rudolfova, jsou proslulé hlavně díky dochovanému popisu. Tou první se mohl pochlubit dánský lékař, historik a starožitník Olav Worm (1588-1654). ${ }^{18}$ Studoval teologii v Marburgu a medicínu v Basileji, byl profesorem na kodaňské univerzitě, kde vyučoval fyziku, medicínu, latinu a řečtinu. Stal se osobním lékařem dánského krále Kristiána IV. (1577-1648). Oženil se s dcerou dánského matematika a fyzika Thomase Finckeho (1561-1656) Dorotheou a po svém otci, starostovi Aarhusu, zdědil značné finanční prostředky.

Jeho zájem se soustředil především na dvě oblasti: první byla dánská historie a raná skandinávská literatura, sbíral a opisoval runové nápisy, z nichž mnohé dnes již neexistují; ${ }^{19}$ a druhou prŕroda. Bylo jen přirozené, že jako významný lékař a vědec budoval také svi̊j kabinet kuriozit, který obsahoval především přírodní artefakty, minerály, zástupce fauny i flóry, ale samozřejmě také výtvory lidských rukou. Své poklady popsal a některé zachytil i obrazem v katalogu Museum Wormianum vydaném rok po jeho smrti. ${ }^{20}$ Před titulním listem je na dvoustraně umístěna rytina Wormova kabinetu: na stropě visí několik vycpaných ryb, ptáků a menších zvířat; mezi dvěma okny jsou na stěně různé parohy; na zemi pod nimi židle a na vedlejší stěně oděvy, ski, pádla, různé nástroje, luky a harpuny, pokrývka hlavy a všelijaké ozdoby, pod nimi figurína muže s oštěpem v ruce, to vše odkazující na etnografické zaměření. Podél zadní stěny a proti oknům se táhne pět polic nad sebou s množstvím dalších exponátů. Nechybí zde ani obrovský kel narvala, pokládaný tehdy obecně za roh bájného jednorožce. Právě Worm dokázal, že kel pochází z narvala, ${ }^{21}$ a nyní víme, že je to ve skutečnosti zub. ${ }^{22}$

Tři spodní police jsou plné různých krabic a bedýnek opatřených na čele cedulkami s latinskými názvy jednotlivých oddílů, na zadní stěně jsou například nad sebou ve dvou policích mušle a lastury s označením „,conchiliata“ a „conchilia“, na vedlejší zdi tři krabice mineralogických exponátů označené „lapides“ a vedle nich extra vydělená síra „sulphur“. Nechybí ani bedýnka označená „,animalium partes“ a samozrejmě ,varia“. Katalog je rozdělen do čtyř

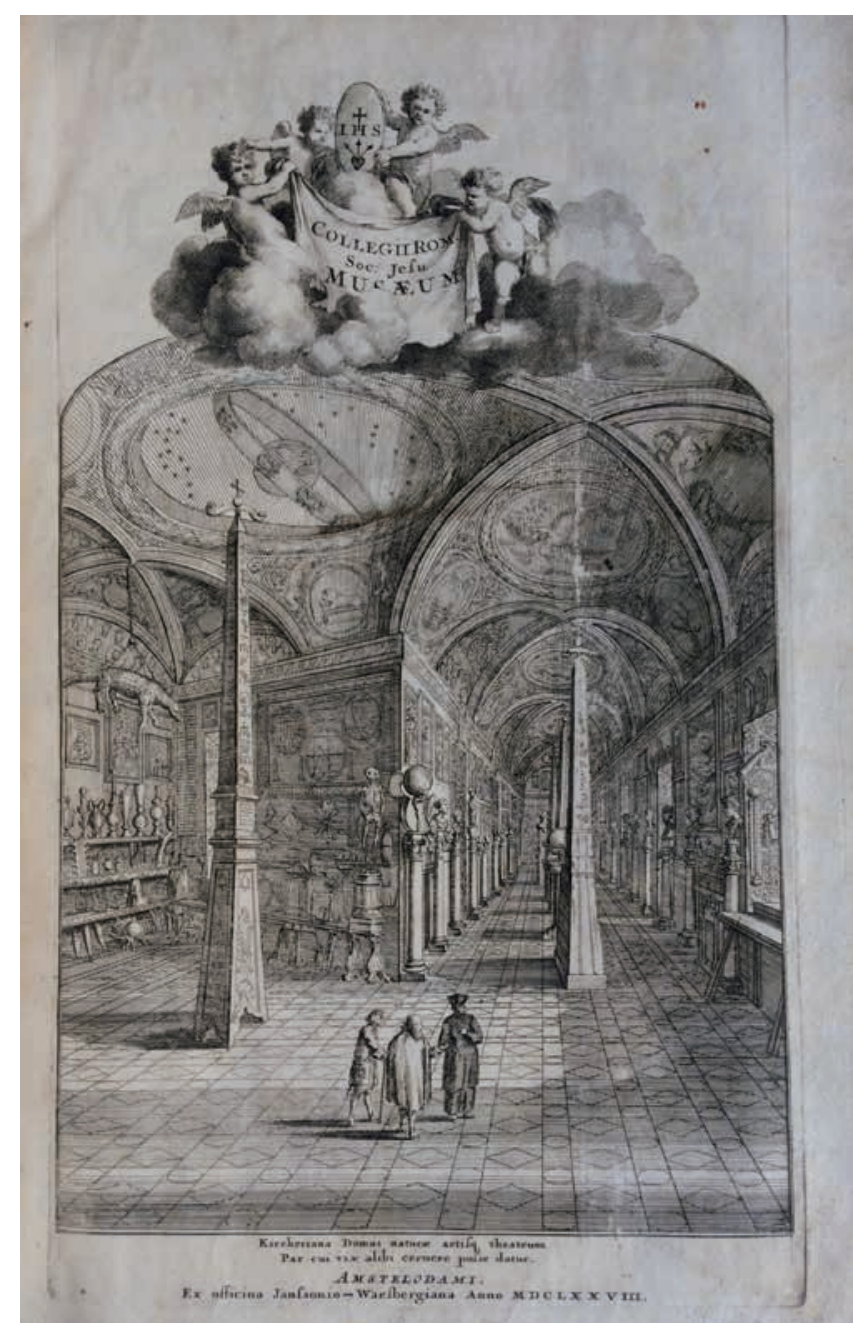

Obr. 4. Pohled do prostor Collegium Romanum v Římě, kde se nacházelo Museum Kircherianum. NK ČR, sign. 23 C 17.

oddílů popisujících exponáty z oblastí mineralogie, rostlinstva, živočišné ř́še a etnografie. Stejně jako v př́ípadě run, i zde zachytil Worm dnes již neexistující druh, nelétavého ptáka alku velkou (Pinguinus impennis). ${ }^{23}$ Jedná se o jediný známý obrázek podle živého exponátu, alku prý dostal z Faerských ostrovů a choval ji v domácnosti.

\section{Museum Kircherianum}

Tím druhým významným počinem je práce německého jezuity a učence Athanasia Kirchera (1602-1680). ${ }^{24}$ Do řádu vstoupil jako 16letý, ve 33 letech se stal profesorem matematiky, filozofie a orientálních jazyků ve Würzburgu, poté studoval v Avignonu. Papež Urban VIII. (1568-1644) jej pověřil výukou matematiky, fyziky a hebrejštiny na Collegium

\footnotetext{
${ }^{17}$ Podrobně o Rudolfových sbírkách včetně jejich smutného konce viz DRAHOTOVÁ 1983, s. 47-60.

${ }^{18}$ Ottův slovník naučný, díl 27, s. 301-302.

${ }^{19}$ Své úlovky zaznamenal v díle Danicorum Monumentorum Libri Sex, viz WORM 1643. NK ČR, sign. 23 H 22.

${ }^{20}$ WORM 1655. Dostupné z: https://www.digitale-sammlungen.de/en/view/bsb11394893?page=,1 [cit. 1. 9. 2021].

${ }^{21}$ WORM 1655, s. $280-287$.

${ }^{22}$ Konkrétně levý špičák horní čelisti. O narvalích klech např. PAZDERA 2005, další informace viz heslo narval na Wikipedii. Dostupné z: https:// cs.wikipedia.org/wiki/Narval [cit. 29. 8. 2021].

${ }^{23}$ WORM 1655, s. 301.

${ }^{24}$ Ottưv slovník naučný, díl 14, s. 256; FLETCHER 2011.
} 


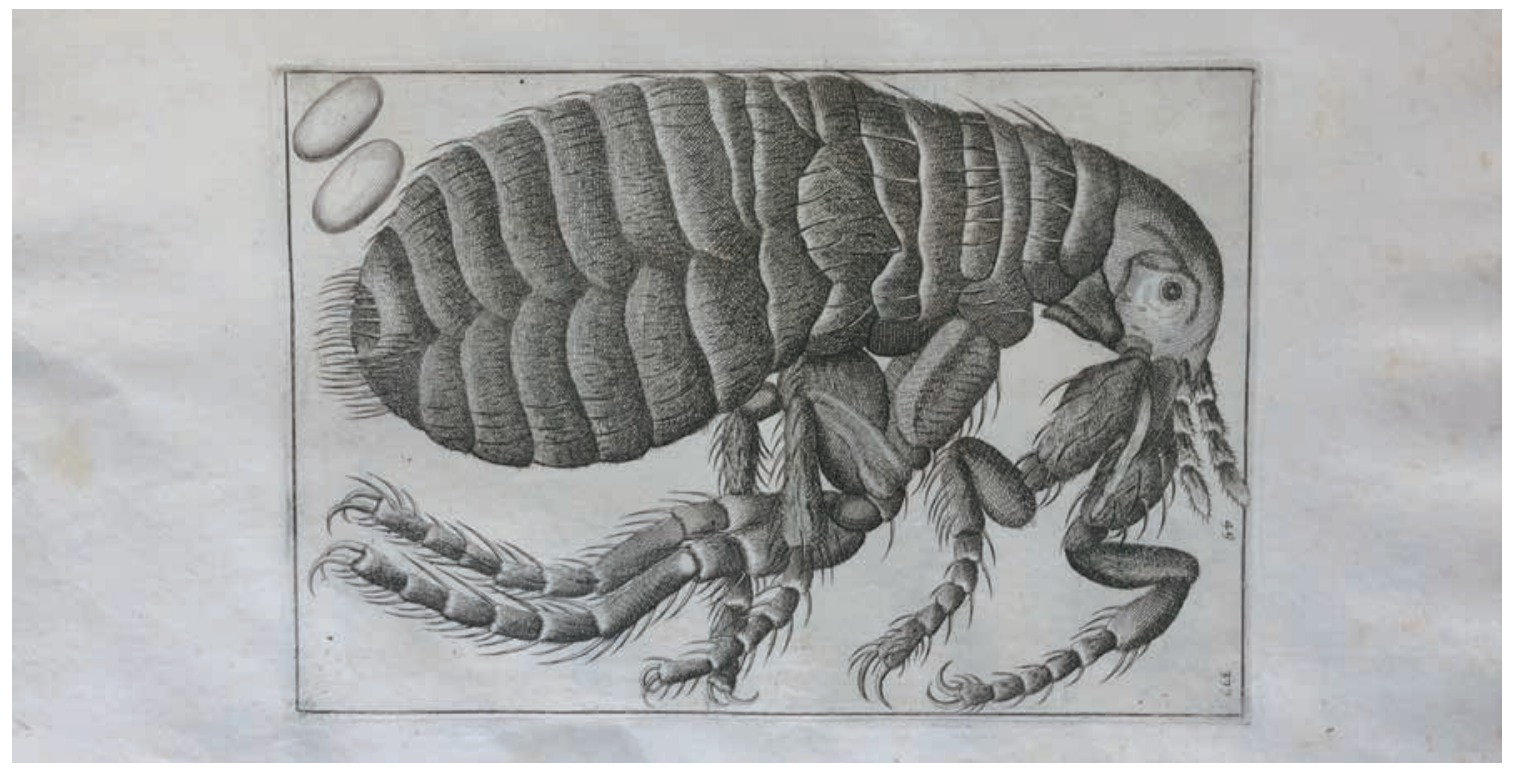

Obr. 5. Díky mikroskopu se do prírodních sbírek dostala i blecha obecná nebo též lidská (Pulex irritans). Do 19. století způsobovala v Evropě, a tudíž i v Čechách, velké problémy jako přenašeč různých bakterií, včetně morových. Nyní ji u nás ve výskytu předběhly blecha psí (Ctenocephalides canis) a kočičí (Ctenocephalides felis), které údajně „na člověka nejdou“. NK ČR, sign. 23 A 11.

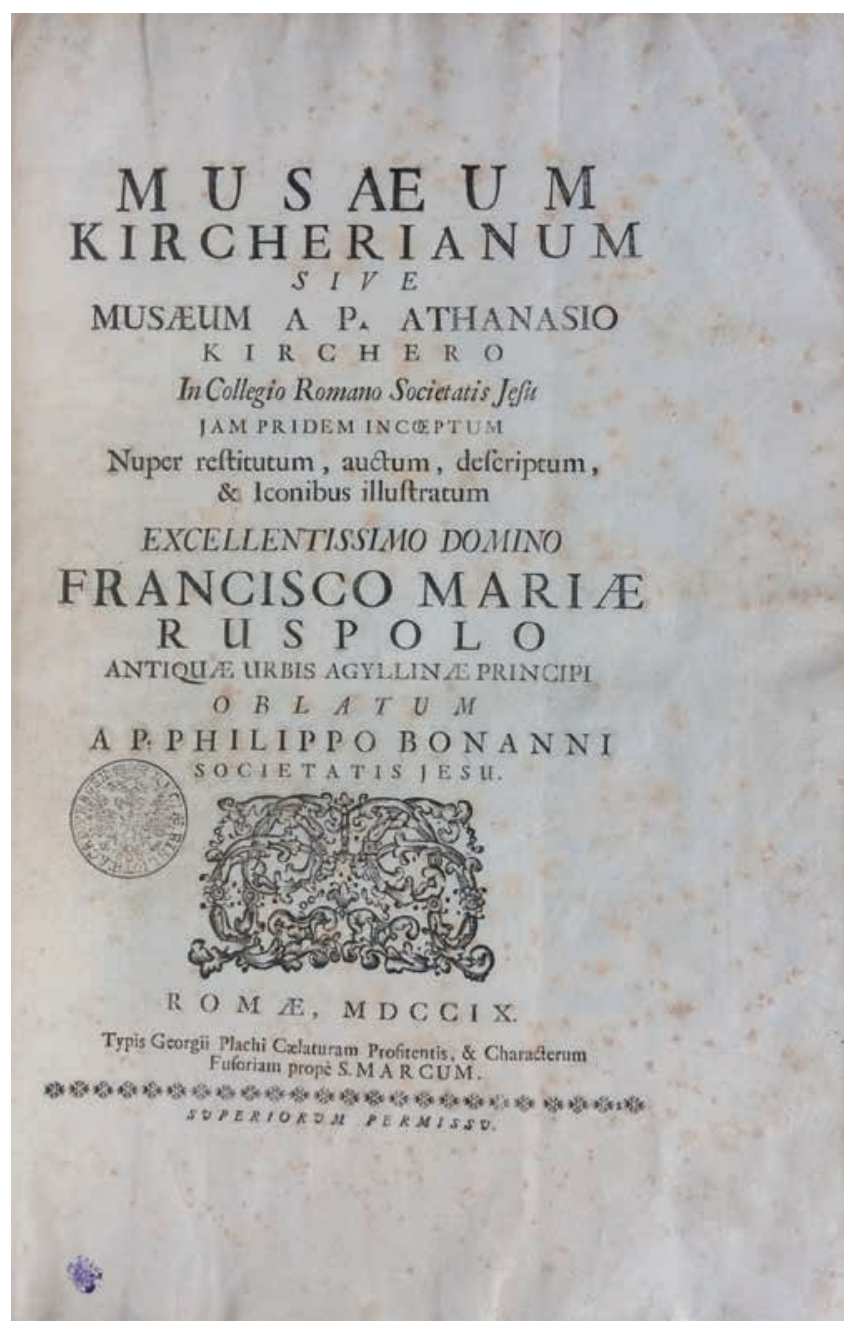

Obr. 6. Katalog muzea vytvořil po Kircherově smrti jeho žák a nástupce Philippo Buonanni (1638-1725). Díky pečlivému popisu dnes známe obsah a tehdejší rozčlenění sbírek. NK ČR, sign. 23 A 11.

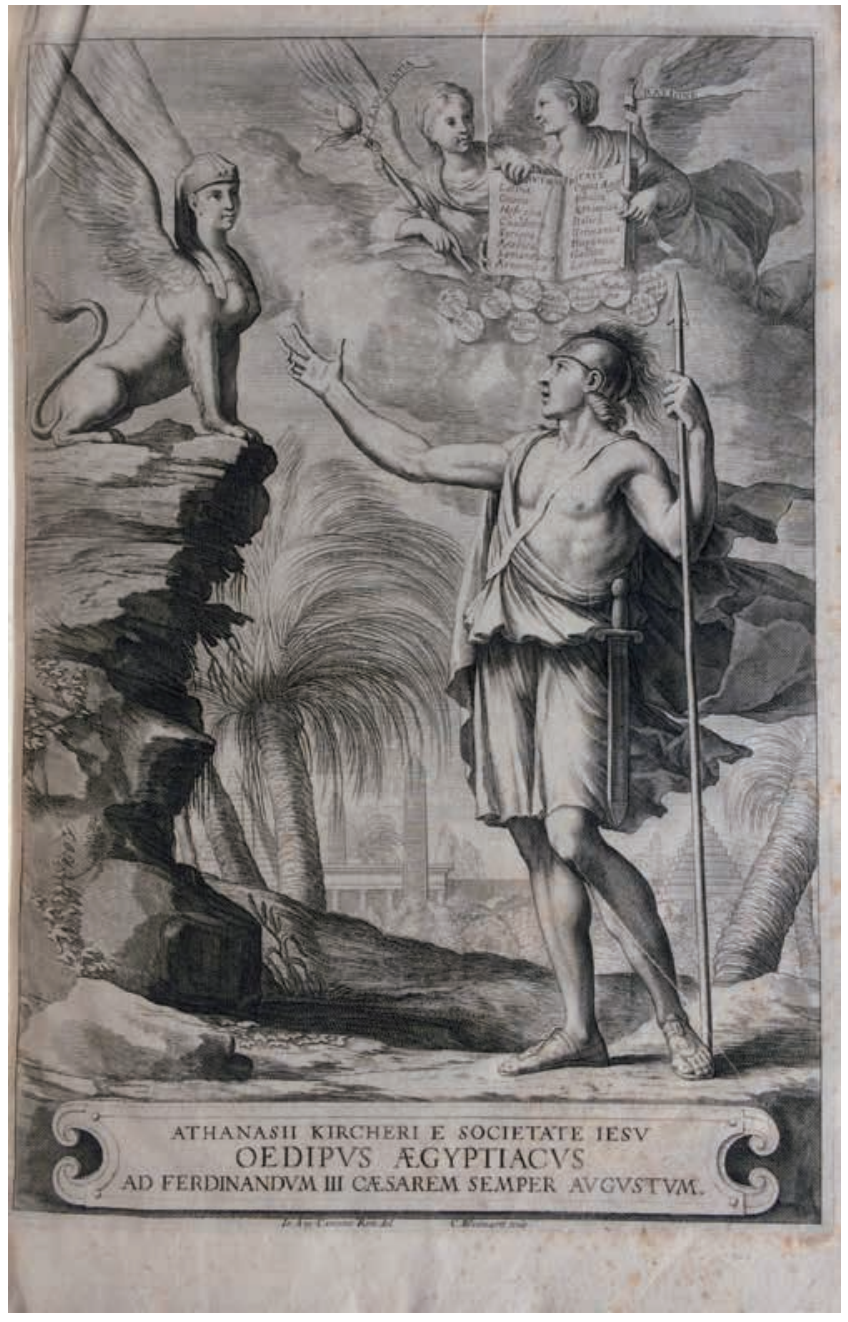

Obr. 7. Kircher díky své zálibě v akustice přistupoval ke čtení hieroglyfů foneticky a vzhledem k jazykové vybavenosti použil pro překlad koptštinu, kterou znal. Rozluštit se mu je sice nepodařilo, ale odhalil velkou podobnost obou jazyků a koptštinu označil za pozůstatek rané egyptštiny. NK ČR, sign. 23 C 20. 
Romanum v Ř́mě a také správou rozsáhlé sbírky sestávající z mnoha starověkých nálezů, zkamenělin, uměleckých děl a různých zvláštností, které koleji odkázal tajemník římského senátu Alfonso Donnino $(† 1650)$.

Kircher následujícího roku 1651 sbírku rozšíril o své vlastní exponáty ze všech možných oblastí vědy, kde nechyběly ani kostry zvířat, mechanické přístroje či hudební nástroje. Vše uspořádal sice ve stylu barokního kabinetu kuriozit, ovšem oproti typickým kabinetům nekladl důraz na zvláštnosti, ale vyzdvihoval především vědecké a naučné účely sbírek. Kromě jiného byl také jedním z prvních vědců pracujících s mikroskopem a díky tomuto př́ístroji zjistil, že mor přenášejí infekční mikroorganismy. V katalogu je vyobrazeno mnoho detailních nákresů hmyzu a jeho ústrojí, což by bez mikroskopického pozorování nebylo možné.

Museum Kircherianum, jak se nazývalo, mělo i svou vlastní knihovnu a brzy se stalo vyhledávaným cílem umělců a učenců. Probíhaly zde kromě běžných návštěv také komentované prohlídky a zřejmě jako první muzeum vůbec používalo své sbírky i pro výuku. ${ }^{25}$

Kircher se zabýval mnoha vědami, bývá označován za jednoho z nejučenějších mužů své doby a pravého polyhistora. Téměř v každé oblasti vědy zanechal své stopy, zajímal se o akustiku, archeologii, geologii, sinologii, medicínu, ale také o sopky, magnetismus či gravitaci. Díky spisu Oedipus Aegyptiacus ${ }^{26}$ vydanému v Římě v letech 1652-1653 je dodnes uznáván za zakladatele egyptologie, i když se mu hieroglyfy rozluštit nepodařilo. ${ }^{27} \mathrm{~V}$ roce 1666 se pokoušel neúspěšně dešifrovat i známý Voynichův rukopis. Georgius de Sepibus uvádí, že je autorem 42 děl, ${ }^{28}$ ale některá z nich jsou dnes považována za kompilace tehdejších vědomostí a znalostí jeho předchůdců i současníků.

\section{Museum Museorum}

Stěžejní práce týkající se sběratelství spatřila světlo světa na počátku 18. století. Německý lékař, člen Německé a Pruské akademie věd, profesor Michael Bernhard Valentini (26. listopad 1657 - 18. březen 1729) byl osobním lékařem lankraběnky Elisabethy Dorothey von SachsenGotha-Altenburg (1640-1709) a také známým a uznávaným sběratelem. Doktorát získal roku 1686 v Giessenu a zde se také později stal profesorem medicíny. V roce 1715 byl zvolen členem Královské společnosti nauk. Roku 1704 vydal ve Frankfurtu nad Mohanem dílo Museum Museorum, ${ }^{29} \mathrm{v}$ té době první bohatě ilustrovanou studii zabývající se přírodovědnými sbírkami v Evropě, kterou lankraběnce věnoval.

První díl je rozdělen na tři knihy, z nichž první obsahuje na stranách 1-106 popisy minerálů, kovů a zkamenělin, ve čtvrté kapitole např́klad najdeme sůl kamennou i kuchyňskou, v osmé potaš a ve 12 . kapitole kamenné neboli

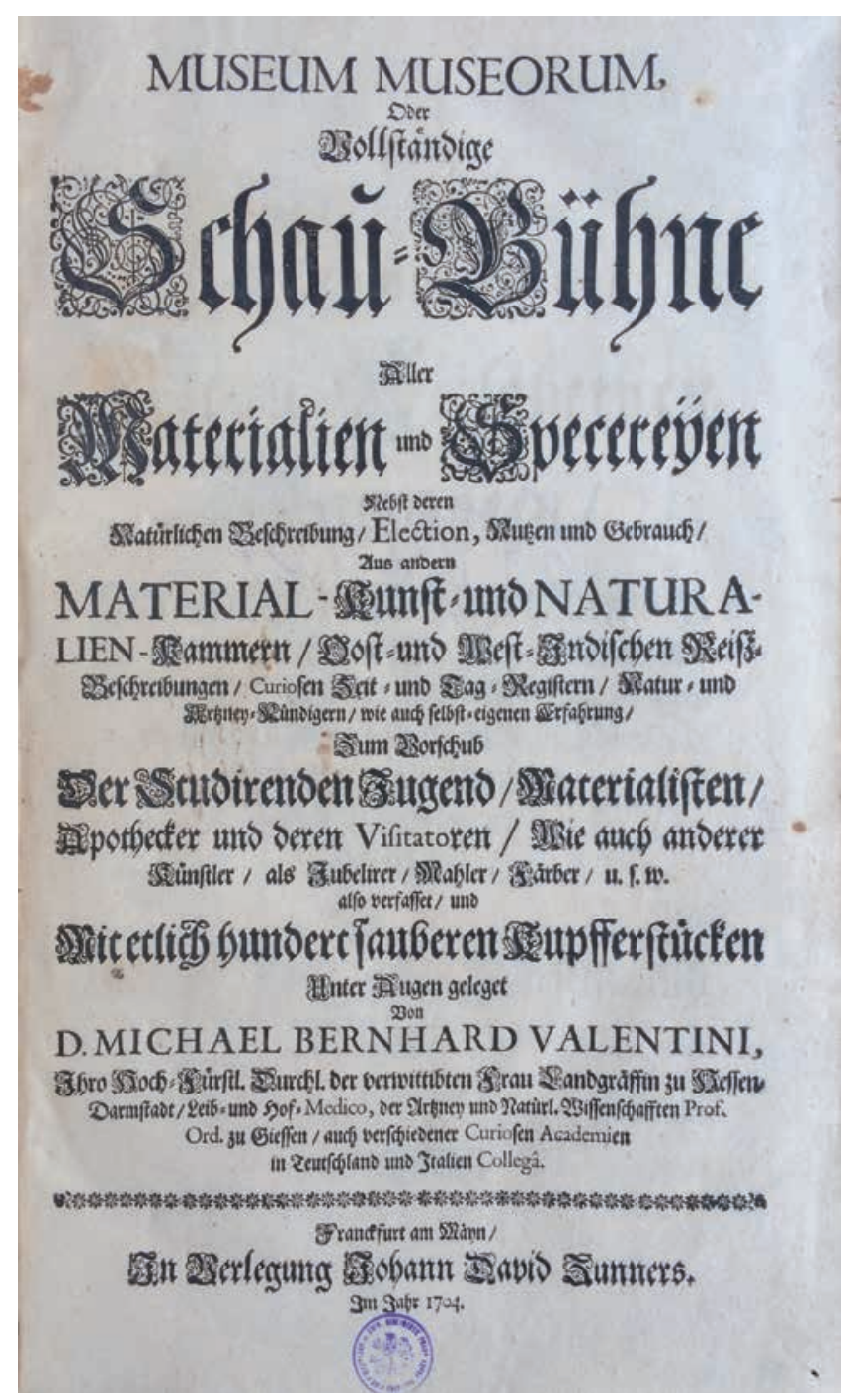

Obr. 8. Museum Museorum představuje nejucelenější přehled barokních kabinetů kuriozit a obsahuje také unikátní seznam světových muzeí. NK ČR, sign. 65 B 216.

černé uhlí. Třicátá osmá kapitola se věnuje mořským korálům. Samotné př́rodniny či různé předměty vzniklé jejich zakomponováním do člověkem vyrobených částí byly vždy velmi vyhledávané a $\mathrm{v}$ žádném pořádném kabinetu kuriozit nesměly chybět. Již z Ovidiových Proměn ${ }^{30}$ bylo známo, že korály jsou zkamenělé kapky krve z hlavy Medúzy, a proto byly nesmírně žádané. Využívaly se nejvíce jako šperky, ale jsou známy i předměty z jiných materiálů korály vykládané.

Druhá kniha se na stranách 107-416 zabývá rostlinstvem, od semen a plodů až po kořeny, od bylinek přes květiny až po stromy, také tropickými druhy, a to včetně jejich lékařského i obchodního využití. Dvacátá kapitola je

\footnotetext{
${ }^{25}$ K muzeu především Kircherův bohatě ilustrovaný katalog Romani Collegii Societatis Jesu Musaeum, který dokončil jeho asistent Giorgio de Sepi. KIRCHER 1678. NK ČR, sign. 23 C 17. Dále BUONANNI 1709. NK ČR, sign. 23 A 11.

${ }^{26}$ KIRCHER 1652-1653. NK ČR, sign. 23 C 20. Dílo je digitalizováno na Google Books a dostupné z: https://books.google.cz/books?vid=N$K P: 1003026711 \&$ printsec $=$ frontcover $\# v=$ onepage $\& q \& f=$ false $[$ cit. 4. 9. 2021].

${ }^{27}$ FRIMMER 1969.

${ }^{28}$ KIRCHER 1678, s. 61-65. NK ČR, sign. 23 C 17.

${ }^{29}$ VALENTINI 1704a. NK ČR, sign. 65 B 216.

${ }^{30}$ Nejnověji OVIDIUS 2005.
} 


\section{Der volffätintigen Natur - unto Material - Sammer}

\section{Das XXXVIII. Sapitel

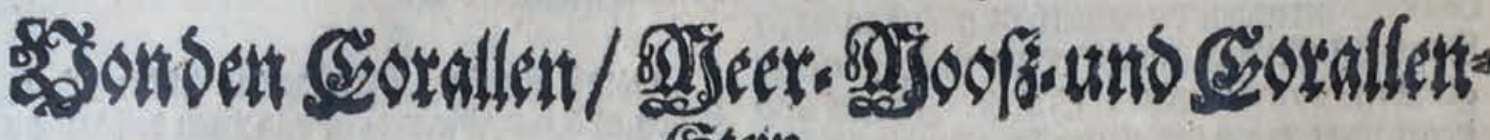 Stein.}

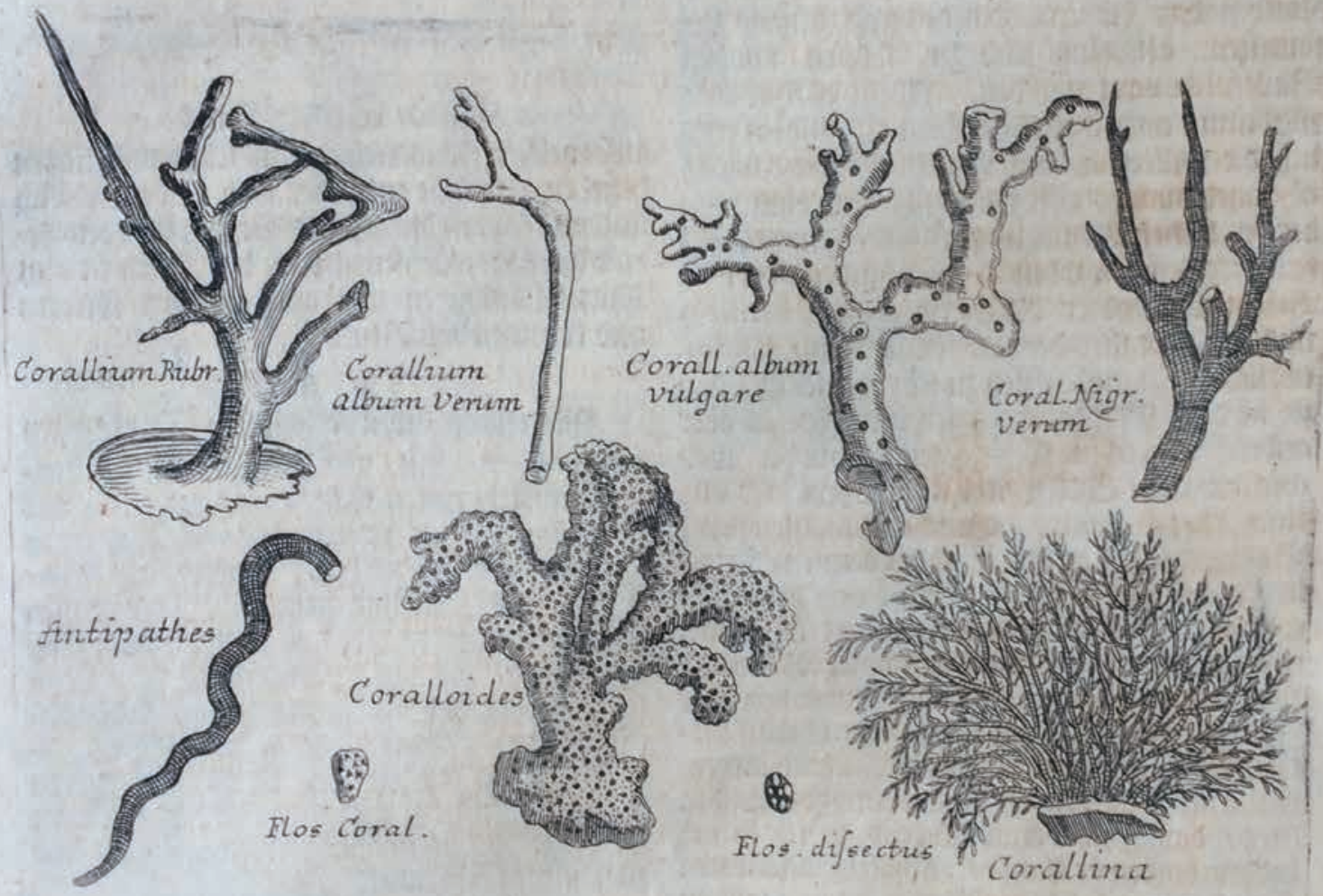

Obr. 9. Nedílnou součástí každé pořádné kunstkomory či kabinetu kuriozit byly mořské korály. NK ČR, sign. 65 B 216 .

věnována kosatcům a 26. kapitola indickému šafránu čili kurkumě. Ve třetí části je popsána rafinace cukru. A ve třetí knize najdeme na stranách 417-520 různé kuriozity, živočichy a zvláštnosti. Hned v první kapitole jsou popsány mumie, následují všemožná zvířata, ptáci, krokodýli, ryby a velryby a ve 30. kapitole nechybí ani bájný jednorožec. Následuje 76 stran nenápadného zamyšlení nad uměleckými a prírodními sbírkami vůbec. Ale jeho součástí jsou také tři velmi cenné strany obsahující seznam 159 muzeí z celého světa, existujících počátkem 18 . století.

Př́mo sbírkám a kuriozitám se věnuje druhý díl Musei Museorum vydaný roku $1714 .{ }^{31}$ Ten autor dedikoval synovi lankraběnky Elisabethy Dorothey Ernstu Ludwigovi von Hessen-Darmstadt (1667-1739), který byl velkým obdivovatelem dvora Krále Slunce, Ludvíka XIV. (1638-1715). Roku 1678 získal titul lankraběte po smrti nevlastního bratra Ludvíka VII. (1658-1678). Díky snaze přiblížit se co nejvíce svému idolu podporoval Ernst Ludwig veškerá umění a věnoval se také módnímu sběratelství, což mělo dohromady za následek obrovské zadlužení celé země, které pak nesli na bedrech jeho potomci.

Tento díl knihy se zabývá detailně sběratelstvím a mapuje stav sbírek na počátku 18. století. Na celkem 196 stranách jsou kameny a minerály, fosilie, tropické rostliny, mušle, mince a různé zvláštnosti. Každou „kuriozitu“ doprovází ilustrace a bohatý popis včetně možných nalezišt'. V celkem 23 kapitolách najdeme staré popelnice a lampy prvních křest’anů, figurální a jinak zvláštní kameny a skály, prehistorické hroty šípů, zkamenělé mušle, ulity a skořápky měkkýšů a mlžů, zkamenělé dřevo, rostliny a ryby, různé rudy a kovy, podivuhodné rostliny a stromy, indické tropické ovoce a zeleninu i mechy. Následují ve 46 kapitolách informace o obchodních aktivitách v jednotlivých oblastech, popis domorodců a místní fauny i nezvyklých předmětů.

${ }^{31}$ VALENTINI 1714a. NK ČR, sign. 65 B 216/adl.1. 


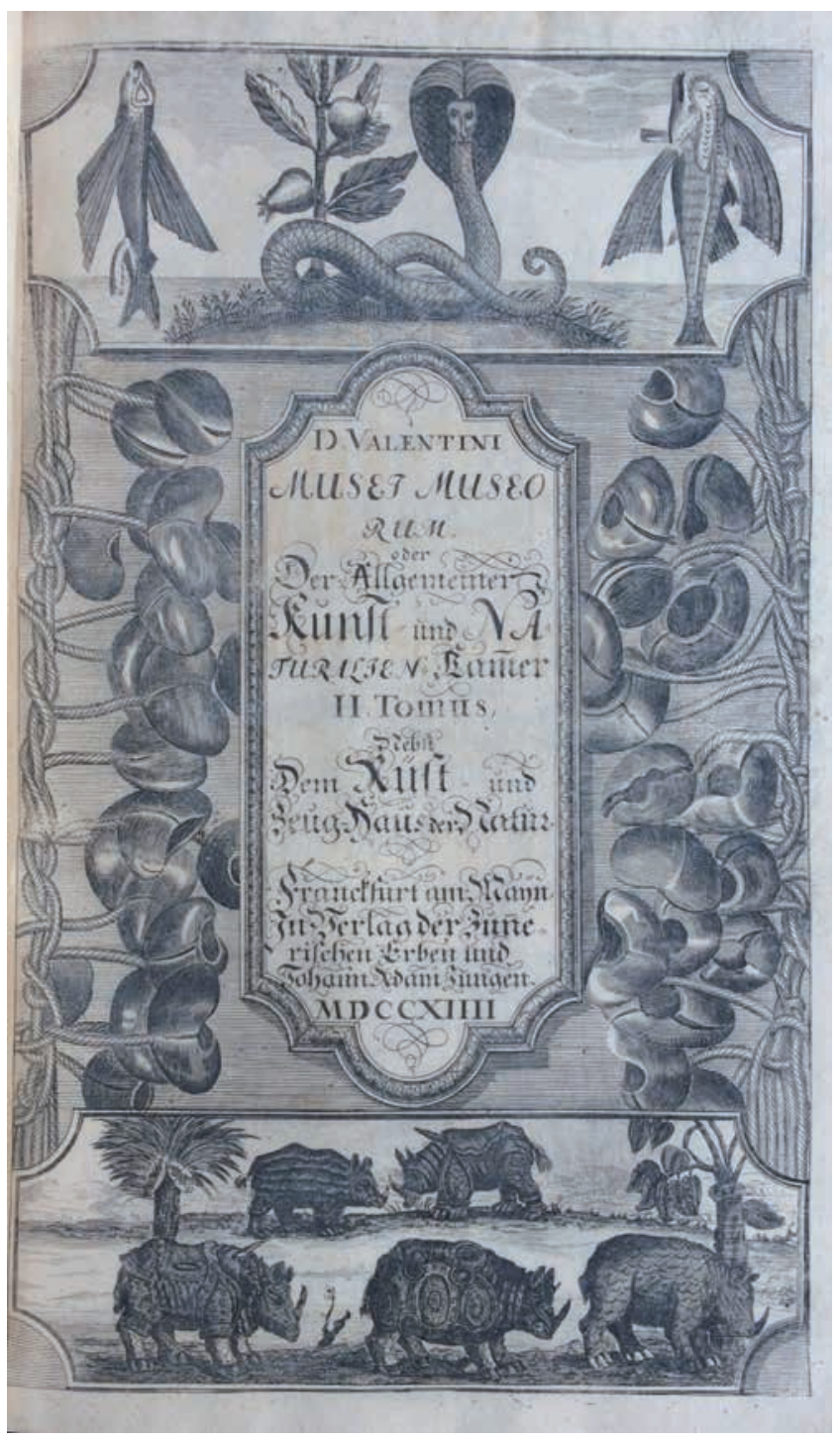

Obr. 10. Druhý díl Musei Museorum je věnovaný přímo sbírkám a raritám v nich obsaženým. NK ČR, sign. 65 B 216/adl.1.

Vše završuje dodatek o 116 stranách, věnující se blíže některým známým kunstkomorám. Je v něm zaznamenán výběrový obsah celkem $24 \mathrm{v}$ té době významných a známých kabinetů kuriozit, a to bud' prímo formou dopisu od majitele, nebo Valentini převzal popis sbírek uveřejněný dříve v jiném díle. Jedná se o císařskou klenotnici a kunstkomoru ve Vídni, královskou francouzskou klenotnici v Saint Denis u Paříže a divadlo anatomie u Královské zahrady ve čtvrti St. Victor, ${ }^{32}$ královskou dánskou kunstkomoru v Kodani, královskou a kurfiřtskou kunstkomoru v Drážd'anech, knížecí kabinet kuriozit a př́rodnin hesensko-kasselského lankraběte v Collegium Carolinum v Kasselu, Loretánský poklad v italském Klausenu, relikvie v katedrále Panny Marie v Cáchách, kabinet kuriozit a př́rodnin v Královské anglické společnosti v Londýně, akademickou zahradu v Leidenu, kunstkomoru lüneburského radního a lékaře Tobiase Reimera, sbírky lékaře a heraldika Christiana

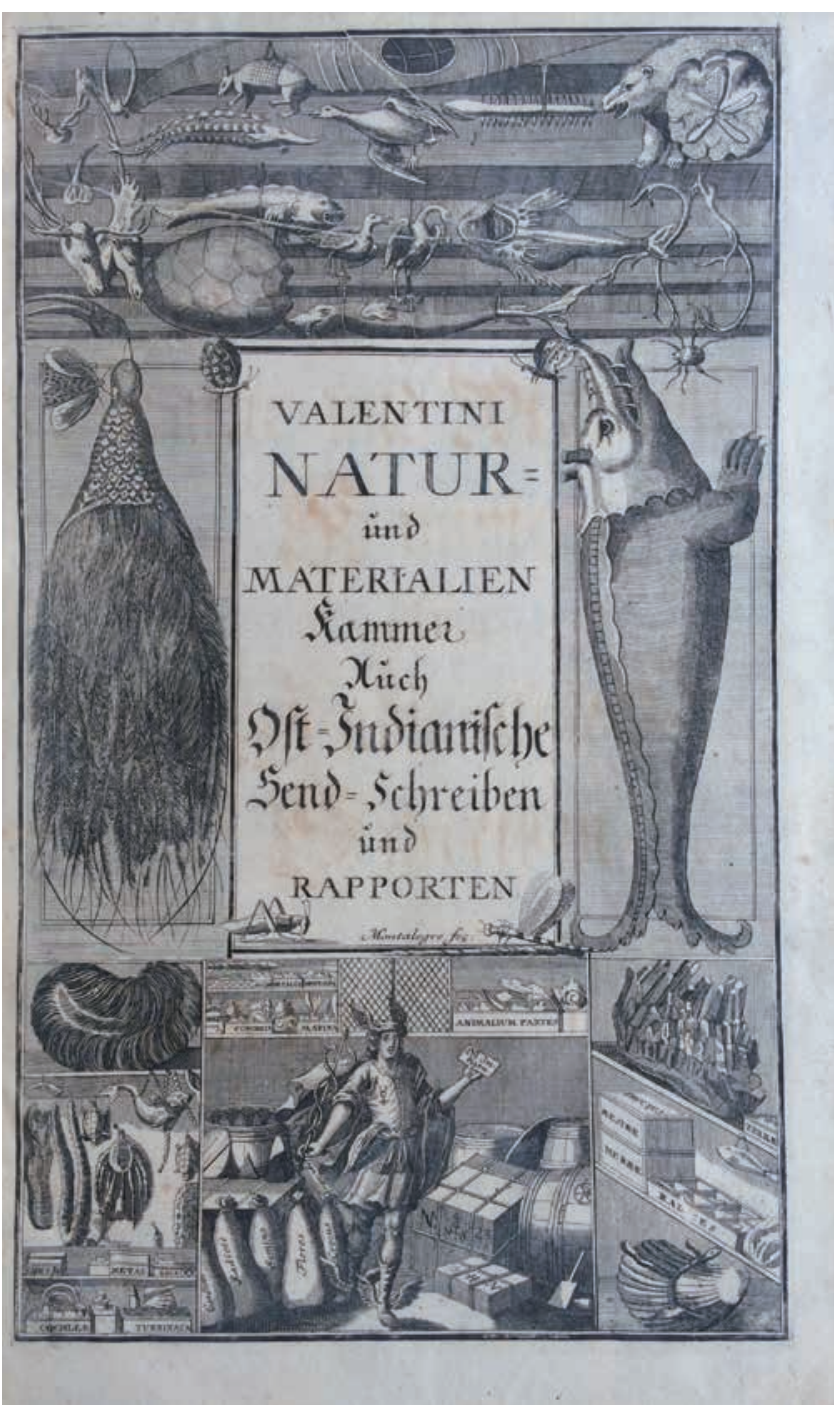

Obr. 11. Poslední, třetí díl rozsáhlé encyklopedie je věnován hlavně fyzice a různým př́strojům a nástrojům. Jeho samostatnou přilohu tvoři kompilace převážně botanických zvláštností Východní Indie. NK ČR, sign. 65 B 216/adl.2.

Maxmiliana Spenera v Berlíně, kabinet př́rodnin lipského starosty Christiana Lorentze von Adlershelma, sbírku zkamenělin lékaře Johanna Georga Kisnera ve Frankfurtu nad Mohanem, kunstkomoru londýnského lékárníka Jamese Petivera, divadlo anatomie v Amsterdamu a Leidenu, matematické rarity univerzity v Giessenu, museum matematika Erharda Weigela v Jeně, anatomický kabinet lékaře a botanika Frederika Ruysche v Amsterdamu, sbírky halberstadtského radního a cestovatele Johanna Konrada Rätzela, museum Eliase Brackenhoffera ve Štrasburku a Gottfrieda Nicolaie ve Wittenbergu a také o jeden anonymní kabinet kuriozit. Výčet uzavírají sbírky samotného autora, Michaela Bernharda Valentiniho, a profesora medicíny, sběratele a zakladatele muzeologie Johanna Daniela Majora.

Rozsáhlá kniha pokračuje ještě třetím dílem, také $\mathrm{z}$ roku $1714,{ }^{33}$ věnovaným hraběti Johannu Fridrichovi

\footnotetext{
${ }^{32} \mathrm{Na}$ místě bývalé Královské zahrady je dnes veřejný park a zároveň zahrada botanická Jardin des plantes. Rozkládá se v 5. pařižském obvodu a Quartier St. Victor je název jedné z jeho městských částí.

${ }^{33}$ VALENTINI 1714b. NK ČR, sign. 65 B 216/adl.2.
} 
Leiningen-Dagsburg (1661-1722). Na 228 stranách se pojednává o fyzice, různých nástrojích a přístrojích v ní používaných, ale také o přírodní filozofii. Jsou zde opět pečlivě popsány a nakresleny akustické a optické přístroje, ale také konkrétní experimenty a pokusy z oblasti prrírodních věd. A konečně poslední, samostatnou část tvoří 119 stran informací z pera různých autorů o převážně botanických zvláštnostech Východní Indie, ${ }^{34}$ i zde vše doprovázejí bohaté ilustrace a podrobné popisy, jak bylo autorovým zvykem.

Valentini nám ve svém díle zachoval věrný obraz evropského sběratelství na počátku 18. století. Jak je vidno z obsahu, jeho monumentální a takřka encyklopedické dílo přinášelo spoustu užitečných informací nejen pro samotné sběratele, nýbrž i pro vědce $\mathrm{z}$ různých oblastí, obchodníky a na své si díky seznamu světových muzeí jistě přišla i laická veřejnost. Je více než pravděpodobné, že toto dílo ovlivnilo vznik mnoha nových soukromých sbírek. Ty významné přetrvaly a dnes o nich máme písemné zprávy. Ale většina malých či méně významných neměla a ani dnes nemá dlouhého trvání, stejně jako vznikaly, tak i zanikaly. Téměř každá sbírka končí se smrtí svého majitele, at' už jako celek rozptýlený v jiné sbírce, nebo rozprodáním po částech. Mnoho sběratelů proto postupem času na své koníčky pamatovalo v závěti a snažilo se jim tak zajistit další život. Obraceli se na významné osoby i různé instituce, nezřídka univerzity či města a položili tak vlastně základy budoucím muzeím se specializovanými sbírkami.

\section{Literatura a elektronické zdroje:}

AUGUSTA 1927: AUGUSTA, Jan Maria. Rukovět's sěratelova. Praha: Nakladatelství L. Bradáče, 1927.

BERGMANN 1844-1857: BERGMANN, Josef Ritter von. Medaillen auf berühmte und ausgezeichnete Männer des Oesterreichischen Kaiserstaates vom XVI. Bis zum XIX. Jahrhunderte, 2 sv. Wien: Tendler \& Schaefer, 1844-1857. BIET et al. 1995: BIET, Christian - DELAMARRE, Claude - MLÍKOVSKÁ, Renáta. Osvícenství a revoluce. Praha: Gemini: Fortuna Print, 1995.

BLACK 2003: BLACK, Jeremy. Evropa osmnáctého stoleti. Praha: Vyšehrad, 2003.

BLOM 2003: BLOM, Philipp. To Have and to Hold: An Intimate History of Collectors and Collecting. London: Penguin, 2003.

BROŽKOVÁ - CIRKL - DRAHOTOVÁ - ROUS SLAVÍČEK 1983: BROŽKOVÁ, Helena - CIRKL, Jiří DRAHOTOVÁ, Olga - ROUS, Jan - SLAVÍČEK, Lubomír. Sběratelství. Praha: Svoboda, 1983.

BUKOVINSKÁ 1997: BUKOVINSKÁ, Beket. Kunstkomora Rudolfa II.: Kde byla a jak vypadala? In: FUČÍKOVÁ, Eliška et al. (edd.). Rudolf II. a Praha. Císařský dvior a rezidenční město jako kulturní a duchovní centrum střední Evropy. Katalog vystavených exponátů, Praha 30. 5. - 7. 9. 1997. Praha: Správa Pražského hradu, 1997, s. 199-208.

BUONANNI 1709: BUONANNI, Filippo. Musaeum Kircherianum sive Musaeum a P. Athanasio Kirchero In
Collegio Romano Societatis Jesu jam pridem incoeptum Nuper restitutum, auctum, descriptum, \& Iconibus illustratum Excellentissimo Domino Francisco Mariae Ruspolo Antiquae Urbis Agyllinae Principi oblatum. Romae: Typis Georgii Plachi, 1709. NK ČR, sign. 23 A 11.

DACOSTA KAUFMANN 1978: DACOSTA KAUFMANN, Thomas. Remarks on the Collections of Rudolf II. The Kunstkammer as a Form of Representatio. Art Journal 38, Autumn 1978, s. 22-28.

DÄMMIG 2012: DÄMMIG, Matthias. Gabriel Kaltemarckts Bedencken, wie eine kunst-cammer aufzu richten seyn mochte von 1587 mit einer Einleintung. In: SYNDRAM, Dirk - MINNING, Martina (edd.). Die kurfürstlich-sächsische Kunstkammer in Dresden. Geschichte einer Sammlung. Dresden: Sandstein Kommunikation, 2012, s. 46-61.

DAVENNE 2012: DAVENNE, Christine. Cabinets of Wonder. New York: Abrams, 2012.

DEMEULEMEESTER 2017: DEMEULEMEESTER, Thijs. Wunderkammer. An exotic Journey through Time. Tielt: Lannoo, 2017.

DOBALOVÁ - HAUSENBLASOVÁ - MUCHKA PURŠ 2014: DOBALOVÁ, Sylva - HAUSENBLASOVÁ, Jaroslava - MUCHKA, Ivan Prokop - PURŠ, Ivo. Hvězda. Arcivévoda Ferdinand Tyrolský a jeho letohrádek v evropském kontextu. Praha: Artefactum, 2014.

DOLÁK 2018: DOLÁK, Jan. Sběratelství a sbirkotvorná činnost muzeí. Bratislava: Univerzita Komenského, 2018.

DRAHOTOVÁ 1983: DRAHOTOVÁ, Olga. Rudolf II. a jeho sbírky. In: BROŽKOVÁ, Helena - CIRKL, Jiří DRAHOTOVÁ, Olga - ROUS, Jan - SLAVÍČEK, Lubomír. Sbératelství. Praha: Svoboda, 1983, s. 47-60.

FINDLEN 1997: FINDLEN, Paula. Kabinety, sběratelství a př́rodní filozofie. In: FUČÍKOVÁ, Eliška et al. (edd.). Rudolf II. a Praha. Císařský dvůr a rezidenční město jako kulturni a duchovní centrum středni Evropy. Katalog vystavených exponátů, Praha 30. 5. - 7. 9. 1997. Praha: Správa Pražského hradu, 1997, s. 209-219.

FLETCHER 2011: FLETCHER, Elizabeth (ed.). FLETCHER, John Edward. A Study of the Life and Works of Athanasius Kircher, „, Germanus Incredibilis “. Amsterdam: Brill Publications, 2011.

FRIMMER 1969: FRIMMER, Steven. The Stone that spoke. And other clues to the decipherment of lost languages. New York: G. P. Putnam's Sons, 1969.

FUČÍKOVÁ - BUKOVINSKÁ - MUCHKA 1991: FUČÍKOVÁ, Eliška - BUKOVINSKÁ, Beket-MUCHKA, Ivan. Umění na dvoře Rudolfa II. Praha: Aventinum, 1991.

GALLIAN 2020: GALLIAN, Nastasia. „Pourquoi un prince luthérien doit-il collectionner les gravures?" Les conseils de Gabriel Kaltemarckt à Christian Ier de Saxe (1587). 124 Sorbonne. Carnet de l'École doctorale d'Histoire de l'Art et d'Archéologie. Sborník z Journée doctorale en Histoire de l'Art de l'ED 124. Paříž: Univerzita Sorbonna, 28. 1. 2016, zveřejněno 13. dubna 2020. Dostupné z: https://124revue. hypotheses.org/4613 [cit. 29. 8. 2021].

${ }^{34}$ VALENTINI 1704b. NK ČR, sign. 65 B 216/adl.3. 
GOOGLE BOOKS: Google Books [online]. Dostupné z: https://books.google.cz/ [cit. 4. 9. 2021].

GRANBERG 1902: GRANBERG, Olof. Kejsar Rudolf II Konstkammare och dess svenska öden och om uppkomsten af drottning Kritmas tafvelgalleri i rom och dess skingrande. Stockholm: Lindström, 1902.

GUTFLEISCH-ZICHE - MENZHAUSEN 1989: GUTFLEISCH-ZICHE, Barbara - MENZHAUSEN, Joachim. „How a Kunstkammer should be formed“: Gabriel Kaltemarckt's advice to Christian I of Saxony on the formation of an art collection, 1587. Journal of the History of Collections, Vol. I., Oxford 1989, s. 3-32.

HALADA 1984: HALADA, Jan. Osvícenství - věk rozumu. Praha: SPN, 1984.

IMPEY - MACGREGOR 2018²: IMPEY, Oliver MACGREGOR, Arthur (edd.). The Origins of Museums: The Cabinet of Curiosities in Sixteenth- and Seventeenth Century Europe. Oxford: Ashmolean Museum, 1985, $2018^{2}$. JANÁČEK 2014: JANÁČEK, Josef. Rudolf II. a jeho doba. Praha: Dobrovský, 2014.

K10 plus: Bibliotheksservice-Zentrum BadenWürttemberg (BSZ) und Verbundzentrale des Gemeinsamer Bibliotheksverbund(VZG/GBV) Göttingen. Verbundkatalog GBV/SWB. Dostupné z:

https://gdz.sub.unigoettingen.de/id/PPN487769457?tify= \{\%22pages\%22:[10],\%22view\%22:\%22info\%22\} [cit. 31. 8. 2021].

KALISTA 2014: KALISTA, Zdeněk. Tvář baroka. Poznámky, které zabloudily na okraj života, skicár̆ problému a odpovédí. Praha: Vyšehrad, 2014.

KIRCHER 1652-1653: KIRCHER, Athanasius. Athanasii Kircheri e Soc. Iesv Oedipvs Aegyptiacvs. Hoc est Vniuersalis Hieroglyphicae Veterum Doctrinae temporum iniuria abolitae Instavratio. Opus ex omni Orientalium doctrina \& sapientia conditum, nec non viginti diuersarum linguarum authoritate stabilitum, Felicibus Auspicijs Ferdinandi III. Avstriaci Sapientissimi \& Inuictissimi Romanorum Imperatoris semper Augusti e tenebris erutum, Atque Bono Reipublicae Literariae consecratum. Tom 1-2. Romae: Ex typographia Vitalis Mascardi, 1652-1653. NK ČR, sign. 23 C 20. Dílo je digitalizováno na Google Books a dostupné z: https://books.google.cz/books? vid $=N$ $K P: 1003026711 \&$ printsec $=$ frontcover $\# v=$ onepage $\& q \& f=-$ false [cit. 4. 9. 2021].

KIRCHER 1678: KIRCHER, Athanasius. Romani Collegii Societatis Jesu Musaeum celeberrimum, Cujus magnum Antiquariae rei, statuarum imaginum, picturarumque partem Ex Legato Alphonsi Donini, S.P.Q.R. A Secretis, munifica Liberalitate relictum. Amstelodami: Ex Officina Jonssonio-Waesbergiana, 1678. NK ČR, sign. 23 C 17.

KNÁPEK 1998-2002: KNÁPEK, Zdeněk. Rukovět' starožitnika a sběratele, 6 dílů. Olomouc: Rubico, 1998-2002.

KUDWEIS 2017: KUDWEIS, Miloš. Numismatika a notafilie. Základy sběratelství zájmových předmètů pro začátečniky. Brno: Edika, 2017.

Kunsthistorisches Museum Wien: Kunsthistorisches Museum Wien. Dostupné z: www.khm.at [cit. 7. 9. 2021]. MacGREGOR 2007: MacGREGOR, Arthur. Curiosity and enlightenment. Collectors and Collections from the
Sixteenth to the Nineteenth Century. New Haven: Yale University Press, 2007.

MAURIES 2011: MAURIES, Patrick. Cabinets of curiosities. London: Thames \& Hudson, 2011.

NEUMANN 1969: NEUMANN, Jaromír. Český barok. Praha: Odeon, 1969.

Ottův slovník naučný: ilustrovaná encyklopaedie obecných vědomostí. Praha: J. Otto, 1808-1909.

OVIDIUS 2005: OVIDIUS. Proměny. Z latinského originálu přeložil, poznámkami a seznamem vlastních jmen opatřil Ivan Bureš. Praha: Plot, 2005.

PAZDERA 2005: PAZDERA, Josef. Tajemství narvalího klu bylo odhaleno, 2005 [online]. Dostupné z: https://www. osel.cz/1602-tajemstvi-narvaliho-klu-bylo-odhaleno.html [cit. 28. 7. 2021].

PICKA 2008: PICKA, Jaroslav. Chvála sběratelství. Sběratelství - cesty za poznáním. Olomouc: Poznání, 2008.

RAVIK 1994: RAVIK, Slavomír. Starožitnosti. Slohy, sbirky, aukce, sběratelé. Praha: Svoboda, 1994.

RAVIK 2010: RAVIK, Slavomír. Velká kniha o starožitnostech. Praha: Československý spisovatel, 2010.

SCHLOSS AMBRAS: Schloss Ambras. Dostupné z: $w w w$. schlossambras-innsbruck.at [cit. 7. 9. 201].

STARK 2008: STARK, Stanislav. Filozofie člověka v historickém kontextu. Plzeň: Katedra filozofie Filozofické fakulty Západočeské univerzity, 2008.

STRADA 1553: STRADA, Jacopo. Epithome thesavri antiqvitatvm, hoc est, IMPP. Rom. Orientalium [et] Occidentalium Iconum, ex antiquis Numismatibus quam fidelissime deliniatarum Ex Musaeo Iacobi de Strada Mantuani Antiquarii. Lvgdvni: apvd Iacobvs de Strada, et Thomam Gverinvm, Excudebat Ioannes Tornaesius, 1553. NK ČR, sign. 23 H 42.

TOMAN 2013: TOMAN, Rolf (ed.). Baroko: theatrum mundi - svět jako umělecké dillo. Praha: Slovart, 2013.

VALENTINI 1704a: VALENTINI, Michael Bernhard. Museum Museorum, Oder Vollständige Schau-Bühne Aller Materialien und Specereyen Nebst deren Natürlichen Beschreibung, Election, Nutzen und Gebrauch, Aus andern Material-Kunst- und Naturalien-Kammern, Oost- und West-Indischen Reiss-Beschreibungen, Curiosen Zeit- und Tag-Registern, Natur- und Artzney-Kündigern, wie auch selbst-eigenen Erfahrung, Zum Vorschub Der Studirenden Jugend, Materialisten, Apothecker und deren Visitatoren, Wie auch anderer Künstler, als Jubelirer, Mahler, Färber, u.s.w. also verfasset, und Mit etlich hundert sauberen Kupfferstücken Unter Augen geleget Von Michael Bernhard Valentini. Franckfurt am Mäyn: In Verlegung Johann David Zunners, 1704. NK ČR, sign. 65 B 216.

VALENTINI 1704b: VALENTINI, Michael Bernhard. Oost-Indianische Send-Schreiben, Von Allerhand raren Gewächsen, Bäumen, Iubelen, Auch andern Zu der natur Kündigung und Artzney-Kunst gehörigen Raritäten, Durch Die Gelehrteste und Berühmteste Europäer, So vormahlen in Oost-Indien gestanden, Als D.Cleyern, Rumphen, Herbert de Jager, ten Rhyne, \&c. Alda gewechselt, Und aus Deroselben in Holländischer Sprach geschriebenen Originalien in die Teutsche Mutter-Sprache übersetzet Von D. Michael Bernhard Valentini, Hoch-Fürstl. Hessen-Darmstättischen 
Archiatro, Prof. Ord. zu Giessen und Academico Curioso. Franckfurt am Mayn: In Verlegung Johann David Zunners, 1704. NK ČR, sign. 65 B 216/adl.3.

VALENTINI 1714a: VALENTINI, Michael Bernhard. Musei Museorum, Oder Der vollständigen Schau Bühne frembder Naturalien Zweyter Theil, Worinnen Die rareste Natur-Schätze aus allen biss daher gedruckten KunstKammern, Reiss-Beschreibungen und andern Curiosen Büchern enthalten, und benebenst einer Neu-auffgerichteten Zeug- und Rust-Kammer der Natur, auch vielen Curiosen Kupffer-Stücken vorgestellet sind, Von D. Michael Bernhard Valentini, Hoch-Fürstl. Hessischen Leib-Medico und Professore zu Giessen. Franckfurt am Mayn: Verlegt von Johann David Zunners sel. Erben und Johann Adam Jungen, 1714. NK ČR, sign. 65 B 216/adl.1.

VALENTINI 1714b: VALENTINI, Michael Bernhard. Neu auffgerichtetes Rüst- und Zeughauss Der Natur, Worinnen Die so wundersame, curiöse, auch sehr nützliche Machinen und Instrumenten, deren sich die heutige Naturkündiger in Erforschung der de natürlichen Ursachen bedienen, zu sehen und zu finden sind. Zum Vorschub aller derienigen, so der Lateinischen Sprach nicht mächtig sind, und dennoch ihren Schöpffer in der Natur zu verehren suchen, Anjetzo zum erstenmal in Hoch-Teutscher Sprache beschrieben, und an Statt des Dritten Theils Des Musei Museorum unter Augen geleget Von D. Michael Bernh. Valentini, Fürstlichen Hessischen Leib-Medico, und der Experimental-Wissenschafft, wie auch der Artzney-Kunst Profess. Ordin- in Giessen. Franckfurt am Mayn: Verlegt von Johann David Zunners sel. Erben und Johann Adam Jungen, 1714. NK ČR, sign. 65 B 216/adl.2.

VILLARI 2004: VILLARI, Rosario (ed.). Barokní člověk a jeho svět. Praha: Vyšehrad, 2004.

Wikipedie. Otevřená encyklopedie [online]. Dostupné z: https://cs.wikipedia.org [cit. 29. 8. 2021].

WORM 1643: WORM, Olav. Danicorum Monumentorum Libri Sex. E spissis antiquitatum tenebris et in Dania ac Norvegia extantibus ruderibus eruti. Hafniae: Apud Ioachimum Moltkenium, 1643. NK ČR, sign. 23 H 22.

WORM 1655: WORM, Olav. Museum Wormianum, seu historia rerum rariorum, tam naturalium, quam artificialium, tam domesticarum, quam exoticarum, quae Hafniae Danorum in aedibus authoris servantur. Amstelodami: apud Ludovicum \& Danielem Elzevirios, 1655. Bayerische StaatsBibliothek, MDZ - Münchener DigitalisierungsZentrum Digitale Bibliothek. Dostupné z: https://www.digitale-sammlungen.de/en/view/ bsb11394893?page $=, 1$ [cit. 1.9.2021].

\author{
Alena Císařová Smítková \\ Národní knihovna České republiky \\ oddělení rukopisů a starých tisků \\ Klementinum 190 \\ 11000 Praha 1
}

